\title{
Magma Chamber Associated to Deep Faults in Copahue Active Volcanic Complex, South America, Suggested by Magnetotelluric Study
}

\author{
E. Borzotta ${ }^{1}$, A. T. Caselli ${ }^{2}$, M. J. Mamani ${ }^{1}, 2018$ \\ ${ }^{1}$ Unit of Geophysics, Argentine Institute of Nivology, Glaciology and Environmental \\ Sciences, IANIGLA, Technological Scientific Center, CONICET, \\ Mendoza, Argentina \\ ${ }^{2}$ Group of Study of Active Volcanoes (GESVA), Institute of Geological Investigations, \\ National University of Rio Negro, Argentina \\ Received 10 May 2018
}

\begin{abstract}
У 1993 і 2008 рр. у кальдері вулканічного комплексу Копауе, Південна Америка, державний кордон Чилі та Аргентини (S 3751'; W 71²10,2') було проведено магнітотелуричні дослідження. Головний ефузивний центр цього комплексу 一 активний вулкан Копауе, що є важливою геотермальною зоною. Наведено результати вивчення кори і дослідження можливих магматичних камер. Інтерпретовано шість магнітотеллуричних зондувань з урахуванням даних щодо геологічної будови і тектоніки району робіт. Виконано два 2D бімодальні моделювання уздовж двох профрілів, приблизно перпендикулярних до простягання гірських порід. Аля магнітоваріаційних досліджень використано два магнітні варіометри. Оцінено вектори індукції (Wiese) Аля трьох магнітотелуричних позицій. Припущено, що потужність літосфери в регіоні становить 60-66 км, положення верхньої і нижньої кори - 8 і 10 км відповідно. Передбачається, що верх магматичної порожнини поблизу нижньої кори знаходиться на глибині 3-8 км за питомого опору 1 Ом·м, що вказує на наявність частково розплавлених або розплавлених порід. Згідно з отриманими даними, ця порожнина може бути генетично пов'язана із системою глибинних розломів у кальдері. На поверхні, над магматичними камерами, можливі теплові потоки в $130-278$ мВт/м ${ }^{2}$, відповідно до емпіричних формул, що пов'язують глибини термопровідних шарів у корі і верхній мантії з тепловими потоками, виміряними на поверхні. Зазначене оцінювання теплових потоків достатньо узгоджується з їх вимірами у свердмовинах, пробурених у кальдері.

На сьогодні магнітотелуричне зондування не є звичайним під час вулканологічних досліджень, тому отримані дані можуть мати важливе значення щодо активності вулкана (нині - жовтий рівень небезпеки), зважаючи на те, що на відстані приблизно в 15 км від нього і в Аргентині, і в Чилі розташовані неселені пункти. Аослідження також важливе з геотермальної точки зору - існує можливість добування енергії без забруднення повітря.
\end{abstract}

Ключові слова: вулкан Копауе, магнітотелуричні дослідження, магматична порожнина, тепловий потік, земна кора.

Introduction and geological outline. In the South American Continent, southward of $33^{\circ} \mathrm{S}$, there are, at least, 60 historically and potentially active volcanoes [Stern, 2004], mainly located along the Andean Range. Among them, the Copahue Volcanic Complex (CVC), located in Patagonia at the Chile-Argentina border (about $37^{\circ} 52^{\prime} \mathrm{S}, 71^{\circ} 09^{\prime} \mathrm{W}$ ), has four ef- fusive centres whose activities began from Pliocene [Pesce, 1989]. The main of these is

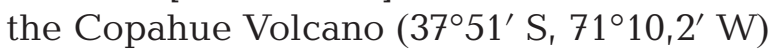
(Fig. 1), seated at the Chile-Argentina border, which constitutes one of the main geothermal areas in Argentina. According to Naranjo and Polanco [2004], twelve eruptions of this volcano were reported during the last 250 years. 
Its last activity period began during 20122013 summer with water vapour and $\mathrm{SO}_{2}$ emissions. Volcano-tectonic seismic events were also produced. At present, it continues

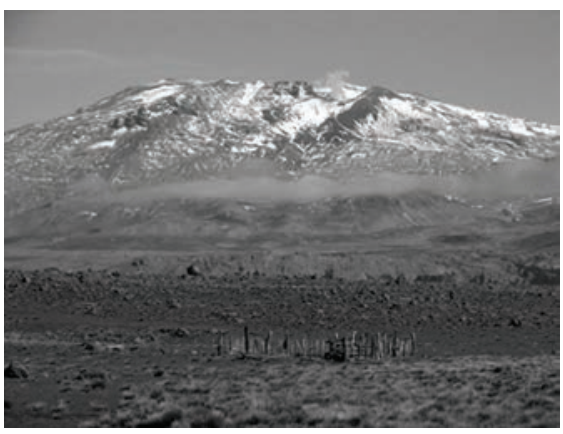

Fig. 1. Photograph of Copahue Volcano taken toward the west, to Argentina - Chile border (Patagonia, Andean Range). Above the crater, it is visible a small plume. its activity with yellow alert (www.sernageomin.cl).The high heat flow in the region and the activity of this volcano encouraged us to study the crust and upper mantle in the zone to investigate the presence and locations of possible magma chambers. The role of faults and lineaments, present in the zone, in the genesis of magma chambers was also investigated. To perform this survey, deep magnetotelluric (MT) soundings were carried out in the region in 1993 and 2008. Data obtained at both campaigns are consistent with each other. A preliminary publication was already done, using field data from the 1993 campaign [Mamani et al., 2000].

According to Pesce [1989] the magmatic evolution of Copahue Volcano region began in the Pliocene (about 5 my ago), and ex-

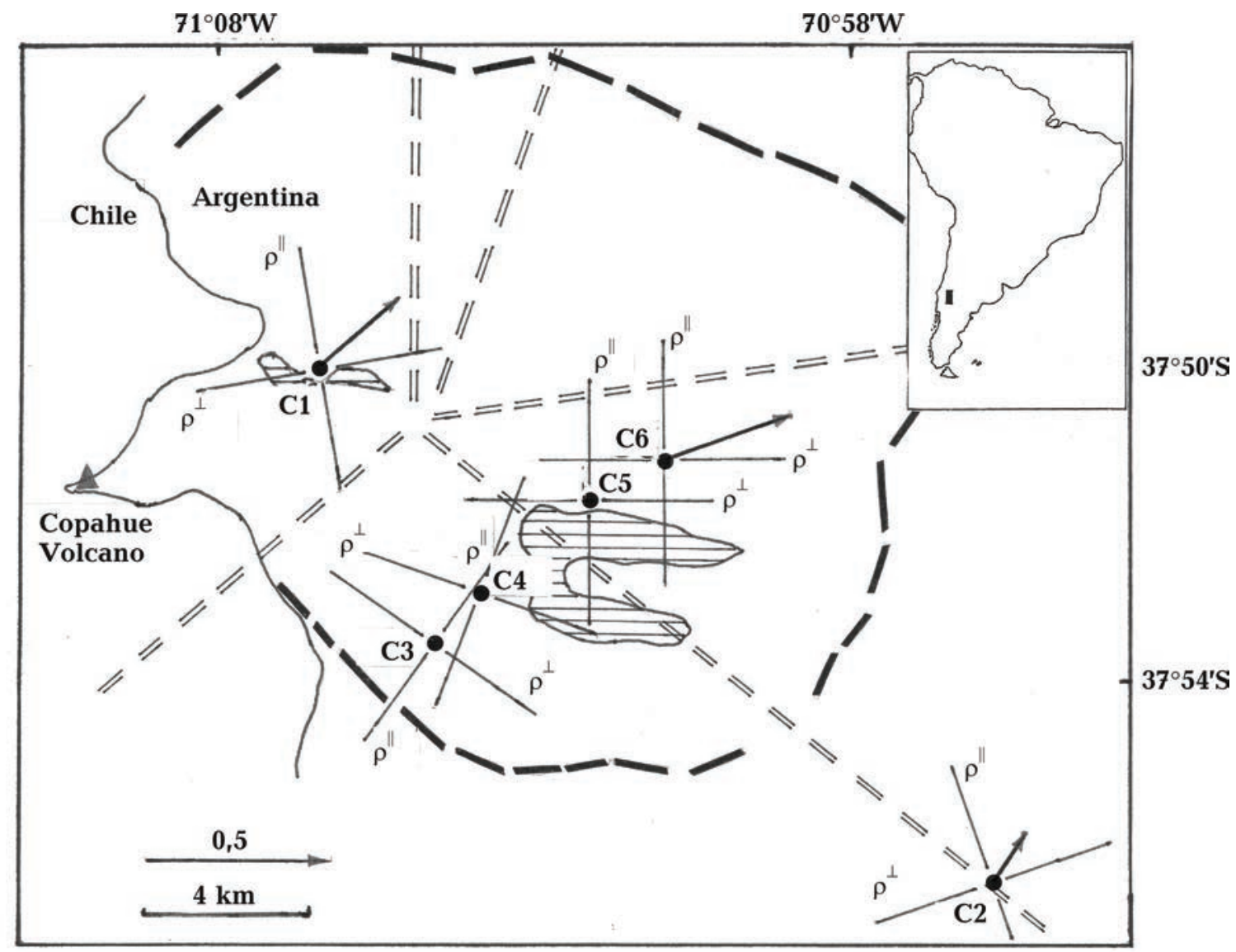

Fig. 2. Map showing the Copahue Volcano location. Dashed heavy lines indicate the border of the caldera. C1, C2, C3, C4, C5 and C6 indicate MT sites. Shaded areas indicate lakes. Principal directions corresponding to periods higher than 60-100 s (lower crust) are showed at each MT site. Principal directions were estimated as the pair of directions corresponding to maximum anisotropy in impedance polar diagrams. Dashed lines indicate suggested faults after [Pesce, 1989]. Three induction (Wiese) vectors are also showed corresponding to average periods of $35^{\prime}$ in $\mathrm{C} 1,45^{\prime}$ in $\mathrm{C} 2$ and 80' in C6, (flux-gate records were only obtained in C1, C2 and C6 site). 

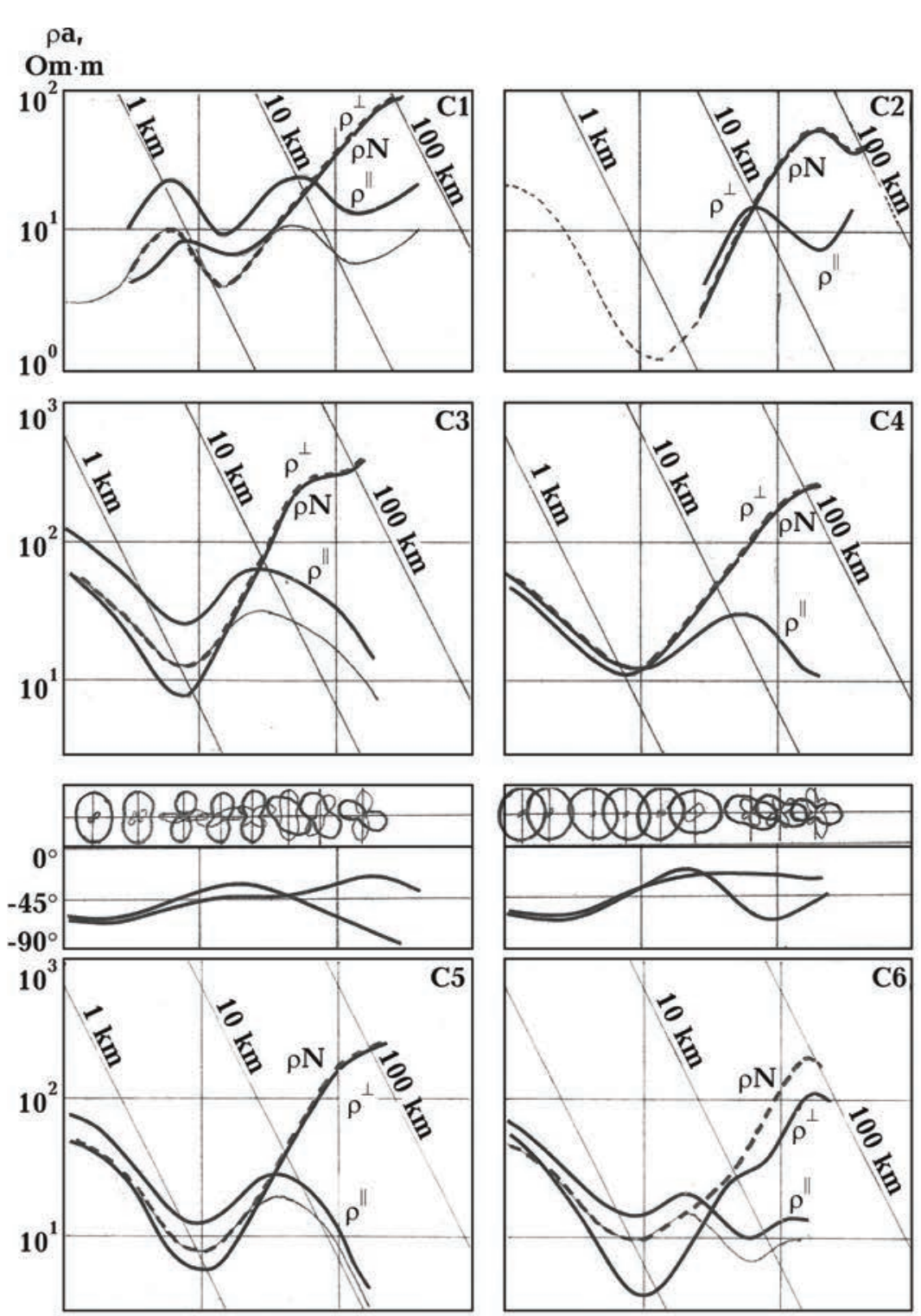

Fig. 3: $a$ - Results from field data processing. Principal apparent resistivity curves (longitudinal and transversal ones) and phase curves are shown (heavy lines) in each MT site. Some impedance polar diagrams are also shown. $\rho \mathrm{N}$ indicates «normal curves» (see text). C1 and C3 sites suggest S-effects in $\rho^{\|}$at high frecuency where they work as transverse curve (see text). Therefore, $\rho \|$ curves were slightly shifted down. C1 and C2 MT soundings (1993 campaign) do not have phase curves and polar diagrams. $\rho \|$ indicates longitudinal curve and $\rho^{\perp}$ the transverse one; $b$ - Error bars corresponding to principal direction curves, parallel and transversal ones at each MT sites at low frecuency, obtained from the field data processing.
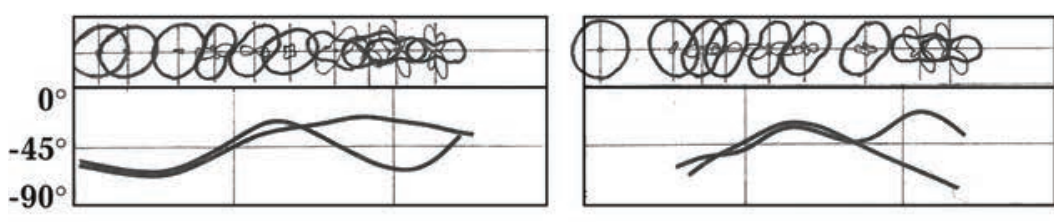

$10^{-1}$

$10^{0}$

$10^{1}$

$10^{2} 10^{-1}$

$10^{0}$

$10^{1} \sqrt{T}, \mathrm{~s}^{1 / 2}$

tended to Holocene. During Pliocene, a big stratovolcano was built. Its volcanic deposits, covering a great surface, observable in Chile and Argentina, are mainly andesitic [Pesce, 1989]. Later, this ancient volcano disappeared after a great eruption and a structural plain, with $2000 \mathrm{~m}$ a.s.l., was performed. At the middle Pliocene, a volcanic-tectonic caldera appeared in the region of former volcano
[Gonzalez Diaz, 2005], (Fig. 2), associated with magma chambers depletion. The depression covers a surface of $350 \mathrm{~km}^{2}$, with $18 \mathrm{~km}$ East-West and 16 km North-South [Gonzalez Diaz, 2005]. Finally a Pleistocene-Holocene new volcano appeared at the SW border of the caldera: Copahue Volcano (3000 m a.s.l.). Its last eruption was produced in 1992, when amorphous sulphur and pyroclastic sulphur 


Om.m
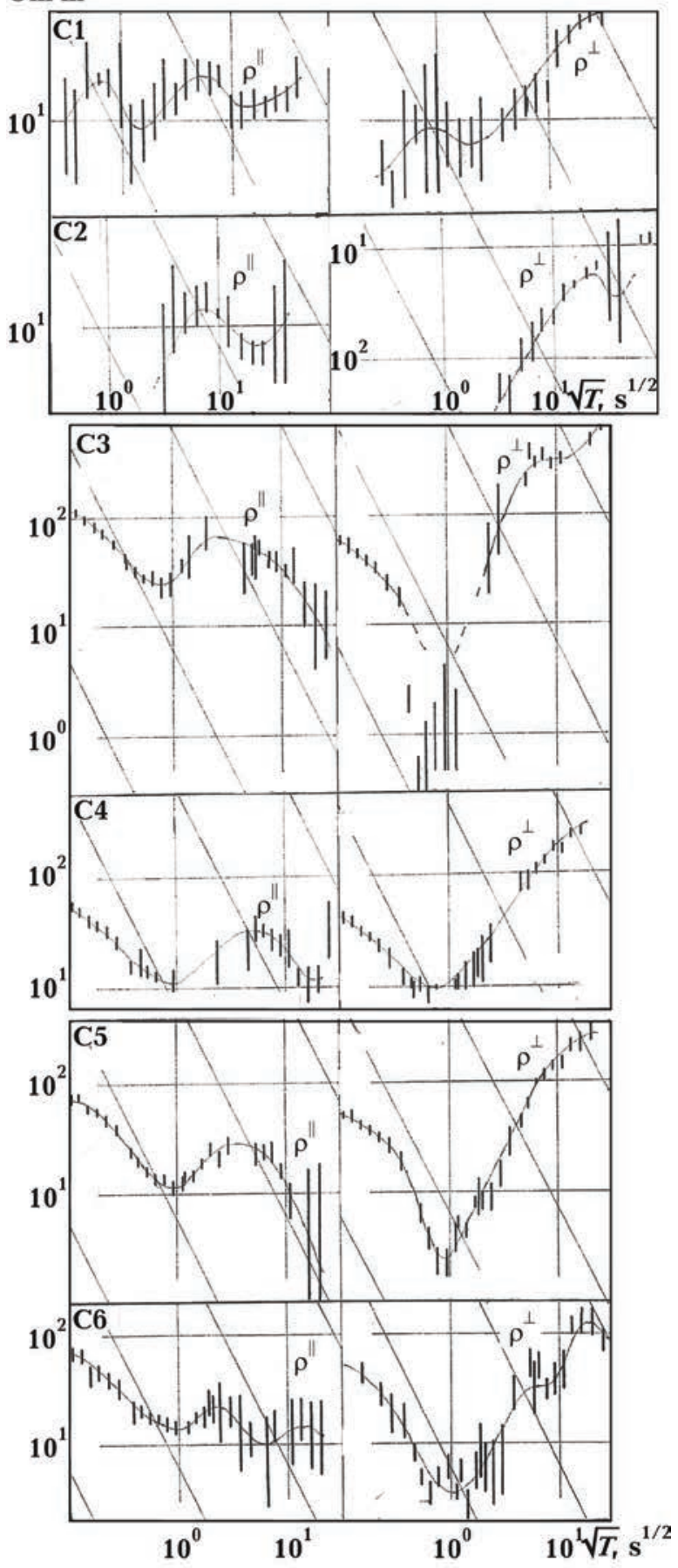

$\boldsymbol{b}$

were ejected with emissions of heavy gases as $\mathrm{SO}_{2}$, and $\mathrm{CO}_{2}$ [Naranjo, Polanco, 2004]. The Copahue Volcano has an elongated shape SW-NE with 9 craters clustered along a belt $\mathrm{N} 60^{\circ} \mathrm{E}$. The easternmost crater is the only active at present, seated at the border
Chile-Argentina. The crater is elliptic in shape with 750 - $450 \mathrm{~m}$ diameter, and an acid lake of $250 \mathrm{~m}$ of diameter is located into the crater (pH 0,18-0,30) [Gonzalez Diaz, 2005].

A deep fault system is suggested in the region [Pesce, 1989] which seems to have had a main role in developing this volcanic complex, according to the results of the present study. According to Pesce (1989) radial faults are present into the caldera (see Fig. 2). The faults with strikes NS and NE-SW seem to be linked to the Liquiñe-Ofqui lineament [Melnick et al., 2006]. At $38^{\circ} \mathrm{S}$, this lineament changes its strike to SW-NE and it is divided in a horsetail-like array [Melnick et al., 2006]. The main branch of this array comes into Argentina at this latitude. Southern of $38^{\circ} \mathrm{S}$ the volcanism in the Andean Range is strongly controlled by this lineament; i. e. the most effusive centres and volcanoes are associated directly or indirectly with this lineament [Melnick et al., 2006]. The present work suggests these deep faults are associated, into the caldera, with a magma chamber thus playing an important role in developing this volcanic complex.

On the other hand, according to [Mas et al., 2000], 12 wells were drilled inside the Copahue Caldera, to about 50-200 m depths to estimate heat flows. The estimate average temperature gradient is $0,121{ }^{\circ} \mathrm{C} / \mathrm{m}$, with maximum heat flows of 288.42, 372,02 and $426,36 \mathrm{~mW} / \mathrm{m}^{2}$. These values were obtained at western and north-western zones of the caldera, close to the border Chile-Argentina [Mas et al., 2000].

Data acquisition and distortion diagnostics. Two MT campaigns were carried out: one of these in 1993, and another one in 2008. Four MT soundings were performed at each campaign. As two sites of 1993 were remeasured in 2008, only 6 MT sounding sites were obtained; five soundings inside the caldera and one outside it (see Fig. 2). Different equipments were used in both campaigns; in 1993, electronic amplifiers and filters built in our Institute (Mendoza, Argentina), and induction coils brought by Dr. H. Fournier from France were used, while a magnetotelluric equipment from Electromagnetic Instruments 


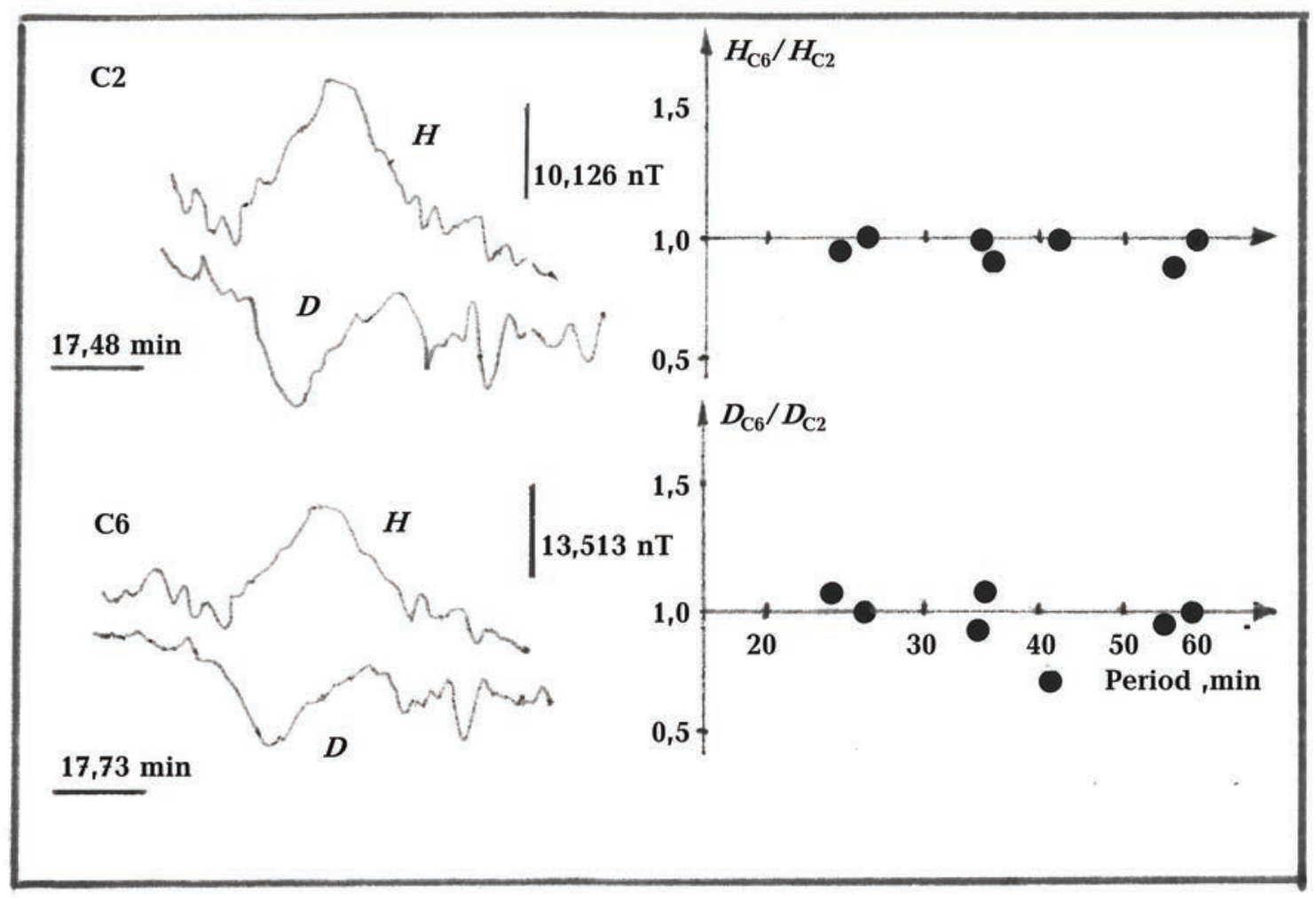

Fig. 4. Magnetovariational study comparing H and D synchronous components in C2 and C6 sites is shown. Magnetic variometers were used to obtain analogic records. An example of magnetograms is shown. The amplitude transfer functions are also shown. An average amplitude transfer function of 0,965 was estimated.

(USA) were used in 2008. Electric dipoles of $100 \mathrm{~m}$ long were used. The measured ranges of periods were $0,10 \mathrm{~s}$ to $2000 \mathrm{~s}$ in 1993 and $0,01 \mathrm{~s}$ to $1000 \mathrm{~s}$ in 2008. Fig. 2 shows MT site locations and principal directions of soundings obtained from data processing, corresponding to periods higher than about $60 \mathrm{~s}$. These directions are referred to geographic NS and EW; i. e., they were corrected by magnetic declination.

Fig. 3, shows all data processing results. Consistent results in all sites are observable. The principal directions were obtained, at each period, from the impedance polar diagram (see Fig. 3,a) as the pair of directions corresponding to the maximum anisotropy in resistivity. The impedance polar diagrams show a rotation of about $90^{\circ}$ when period increases. As a consequence the resistivity curves cross each other. This behaviour can be interpreted as suggesting the presence of two tectonic structures at different depths: a shallow one in WE directions and a deeper one NS into the basement.

In order to carry out the distortion diagnostics the geological structure could be considered as constituted by two parts: a) a structure with only horizontal layers and a basement; i.e., a normal structure (1D), b) another structure superposed to the first one, constituted by bodies, blocks, conductivity anomalies etc, which produces lateral heterogeneities, and distortions in MT curves. To characterize the first structure, the estimation of the "normal curve» in each MT site was made. This curve is that corresponding to an homogeneous horizontal model with a vertical variation of resistivity equal to that existing on the MT site [Berdichevsky, Dmitriev, 1976, p. 165]. The estimation of the normal curve at each site can be made by comparing both principal curves of the site, taking into account only 
those characteristics present in both curves. It is useful also to compare all MT curves in the study zone. All $\rho \mathrm{N}$ curves should be rather similar in shape mainly if the study zone is not too large. This information even though it may not be accurate allows us to obtain an overview of the basic structure in the region, which is then used, in conjunction with distortion information, to make 2D modelling.

In the present case, at all MT site, there is one principal curve suggesting the presence of a conductive body from about 10 - 40 s of period and higher (see Fig. 3). As this conductive body is not suggested by the other principal curve, we may conclude that the conductive body is not a conductive layer but an elongated body with strike parallel to the principal direction in which it is detected. This principal direction curve with induction distortion is thus defining the longitudinal curve $\left(\rho^{\|}\right)$at large periods [Berdichevsky, Dmitriev, 1976]. The longitudinal curves, thus characterized, correspond to strikes from about $\mathrm{N} 19^{\circ} \mathrm{W}$ to $\mathrm{N} 36^{\circ} \mathrm{E}$. Therefore, these curves are indicating the presence of an approximately NS elongated conductive body into the basement. The parallelism between this longitudinal principal curve $\left(\rho^{\|}\right)$directions and the strike of deep faults showed in Fig. 2 is suggesting a possible link between this conductive body and faults into the caldera. On the other hand, the other principal curve $(\rho \perp)$, at C3, C5 and C6 sites suggests induction distortions at low periods (about $1 \mathrm{~s}$ ) (see Fig. 3,a). They could be produced by current channelling running approximately in WE direction, at $1 \mathrm{~km}$ depth, into the basin, in the caldera. Therefore, as induction distortions seem to be present at both principal curves ( $\rho$ ll and $\left.\rho^{\perp}\right)$, a 3D character is thus suggested for the crust into the caldera; if tectonic were strictly $2 \mathrm{D}$, only induction distortions are possible in longitudinal curves and galvanic distortion in transversal ones [Berdichevsky, Dmitriev, 1976]. The average strike direction of $\rho^{\perp}$ at about $1 \mathrm{~s}$ of period is EW. Thus, we can consider two tectonic roughly $2 \mathrm{D}$, instead a $3 \mathrm{D}$ one, in the caldera: a shallow one with strike EW, which is consistent with geological observation [Melnick et al., 2006], and another one, deeper into the basement, roughly NS. Therefore, as a consequence of these two tectonic structures, the principal curve denoted as $\rho^{\perp}$ at large periods has, at lower period, a behavior likes $\rho \|$ because of the current channelling near surface (see Fig. 3).

To estimate the normal curve $(\rho \mathrm{N})$ at each site, the low period branch of $\rho$ ll and large period branch of $\rho^{\perp}$ was used, thus avoiding the induction distortions. Taking into account also the local character of this study, a consistent depth of the intermediate conductive layer (asthenosphere?) was considered as a guide in order to estimate $\rho \mathrm{N}$ curves. Therefore, as an approximation the $\rho \mathrm{N}$ curves at C1, C3, C5 and C6 sites at low periods were shifted down to fit the $\rho^{\perp}$ curve at high periods (Fig. 3, a). This figure shows the MT principal curves at each location and the normal curve $(\rho N)$ thus estimated at each site. The normalization at $\mathrm{C} 6$ does not seem to be so reliable. In fact, the $\rho^{\perp}$ curve at this site shows at about $10 \mathrm{~km}$ depth a structure which was rejected in order to estimate the normal curve because this structure is not observable at C5 site located at only 2,2 km from C6 (see Fig. 3,a).

Interpretation and discussion. A magnetovariational study was carried out to describe the regional current channelling context. The magnetovariational study is highly reliable to describe large conductive features, i.e. conductivity anomalies in the crust and upper mantle [Rokityansky, 1982, p. 300]. Three real induction Wiese vectors were estimated at C1, C2 and C6 sites (see Fig. 2), corresponding to $35^{\prime}, 45^{\prime}$ and $80^{\prime}$ as average periods respectively. These MT locations were the only ones where flux-gate recordings were obtained. These arrows point toward NE. The modules and directions of these vectors are roughly consistent with those estimated, between $38^{\circ} \mathrm{S}$ and $41^{\circ} \mathrm{S}$ in southern Chile, at $54^{\prime}$ of period [Brasse et al., 2009]. Following these authors, the induction vectors can be explained as an effect produced by the coast-effect (from Pacific Ocean) and a fractured lower crust with some 2D conductivity anomalies running about $\mathrm{N} 45^{\circ} \mathrm{E}$ [Brasse et al., 2009]. Therefore, our magnetovariational study suggests an extension of such structure 


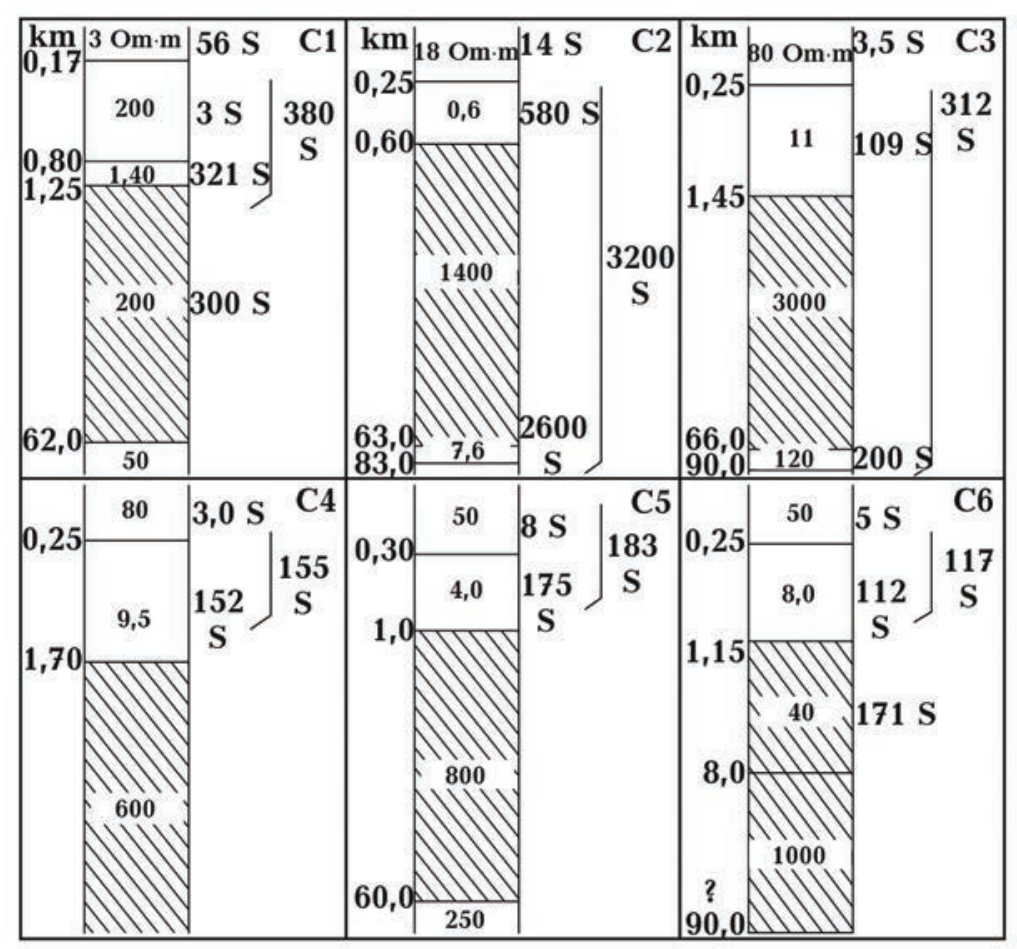

Fig. 5. 1D modelling results, corresponding to $\rho$ N curves, at all MT sites, i. e., for each MT site, only the estimated normal curve was used for 1D modelling. The structures in the first $400 \mathrm{~m}$ depth in all sites are only an approximation (see text). The depth of asthenosphere suggested in C6 (90 km) is not consistent with the other MT sites, possibly indicating an S-effect. S indicates longitudinal conductance in Siemens $\left(\Omega^{-1}\right)$. Shaded areas indicate basement zones.

northward of $38^{\circ} \mathrm{S}$. In addition, synchronous horizontal $\mathrm{H}$ and D magnetograms from $\mathrm{C} 2$ and $\mathrm{C} 6$ sites were compared (Fig. 4). Thus, HC6/HC2 and DC6/DC2 were estimated and amplitude transfer functions 0.96 and 0.97 respectively were thus obtained to periods from $24^{\prime}$ to $60^{\prime}$, indicating a rather similar integrate conductivity at both locations in this range of periods.

1D modelling results corresponding to normalized MT curves are shown in Fig. 5. The first 300 - 400 m depth in the models is only an approximation because the used MT equipment does not give information in this range of depth. The resistivities in the basement, inside the caldera, range among 200 to $3000 \Omega \mathrm{m}$. The depths of the top of basement inside the caldera range among $1,0 \mathrm{~km}$ to $1,7 \mathrm{~km}$; meanwhile the top of basement at C2 site (outside the caldera) is suggested at about $600 \mathrm{~m}$. Therefore, taking into account that the surface into the caldera is about $300 \mathrm{~m}$ deeper than outside it, an estimate of base- ment's subsidence inside the caldera between 700 to $1400 \mathrm{~m}$ respects to the surrounding region is thus obtained. On the other hand, $1 \mathrm{D}$ modelling results show one conductive layer (asthenosphere?) at 60-66 km depth, thus suggesting a lithospheric thinning; even though the evidence (see Fig. 3, a) would not be completely reliable. In fact, only $\mathrm{C} 2$ and C3 give a rather good evidence of this layer, meanwhile in $\mathrm{C} 1$ and $\mathrm{C} 5$ the evidence is feeble and not observable in C4. C6 shows the possible asthenosphere at about $90 \mathrm{~km}$ depth which is not consistent with the others sites; thus it could be indicating an S-effect. In fact, from Fig. 5, C6 MT site shows an integrated conductivity above the basement, lower than in the other locations: only 117 Siemens. Therefore, evidence suggests the presence of a basement lifting zone in $\mathrm{C} 6$ site. The lithospheric thinning here suggested, is consistently indicated in [Folguera et al., 2003].

Induction distortions at large periods in longitudinal curves (see Fig. 3, a) are con- 


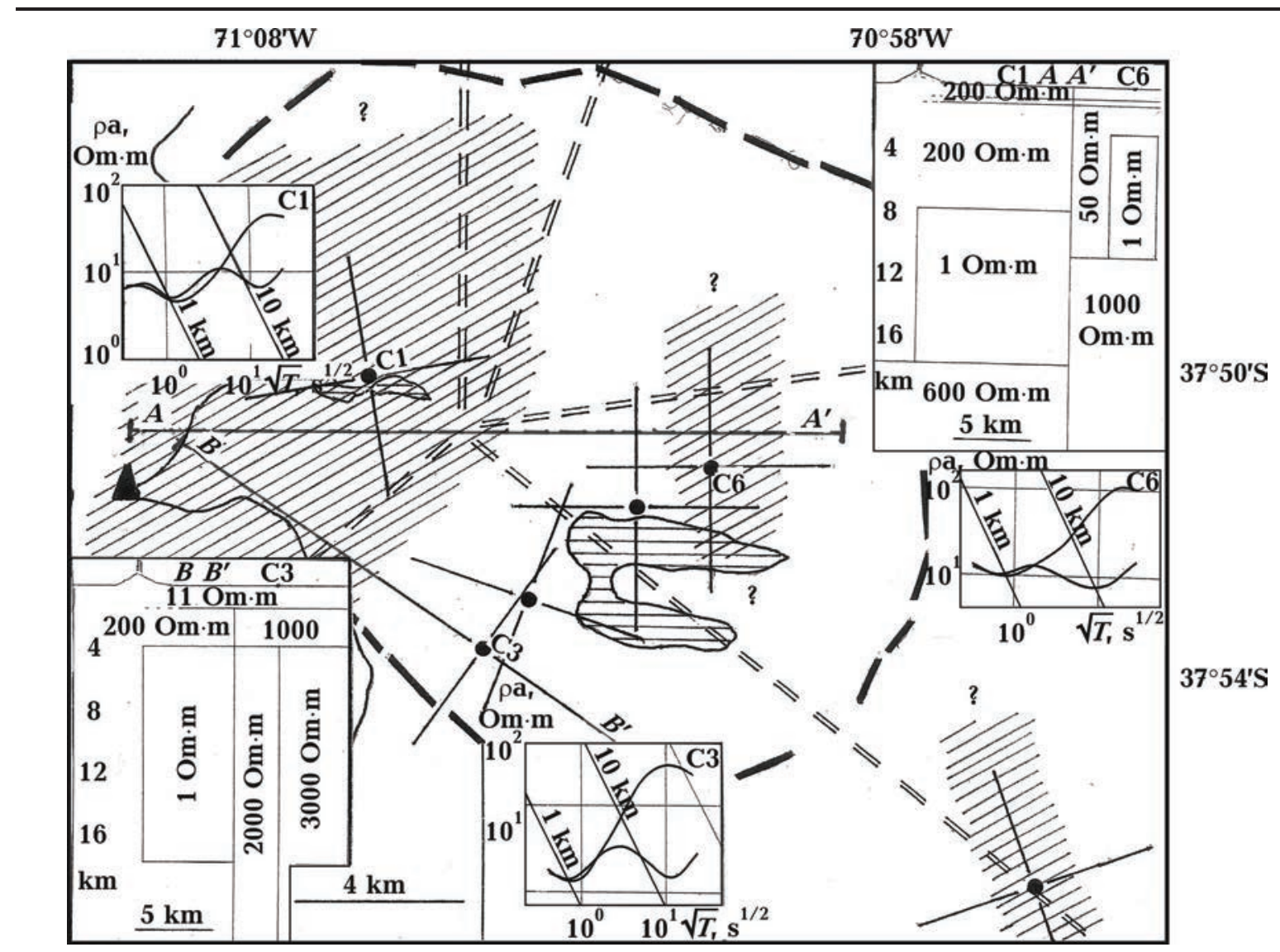

Fig. 6. On a map of the volcanic caldera, two profiles $\mathrm{AA}^{\prime}$ and $\mathrm{BB}^{\prime}$, perpendicular to tectonic strikes are indicated. Along these profiles, 2D bimodal modellings were carried out. The figure shows the best models at both profiles with fit the best field data (compare these MT curves at C1, C3 and C6 sites, obtained from 2D modelling, with field curves in Fig. 3).

sistently indicating a high conductivity body in the basement with an average top depth of about $3-8 \mathrm{~km}$ depth. Taking into account the possible lithospheric thinning, this body is considered to be seated at the lower crust. In addition, the parallelism between the $\rho \|$ principal directions at large periods at $\mathrm{C} 3, \mathrm{C} 4$, C5 and C6 sites and the suggested deep fault strikes at the western portion of the caldera (see Fig. 2), are suggesting a possible genetic association. Therefore, it is assumed that the conductive body is not located beneath the MT sites but westward of them, linked with the NS fault zone. In order to describe this conductive body suggested by the present distortion and checks the tectonic model we are proposing, two 2D modelling were accomplished along $\mathrm{AA}^{\prime}$ and $\mathrm{BB}^{\prime}$ profiles (Fig. 6), using a program after [Wannamaker et al., 1987]. It was assumed a 2D tectonic structure in the basement with an approximate strike NS, parallel to the Andean Range. To perform the 2D modelling, a profile was constructed, including the lateral homogeneous structure arising from 1D modelling of normal curves; and superposed to which the estimated geological structure with lateral heterogeneities, arising from distortions in curves.

Results of 2D modelling corresponding to proposed structures at both profiles are consistent with field data results (see Fig. 3), showing that the proposed structure underneath the caldera, is one among other possible and acceptable structures; the one presented here is that considered the closest to the true, according to the geological evidence and distortion analysis. At the western region of the caldera (see Fig. 6), 2D modelling results confirm our proposed structure: a high conductive body with $1 \Omega \mathrm{m}$ of resistivity, 


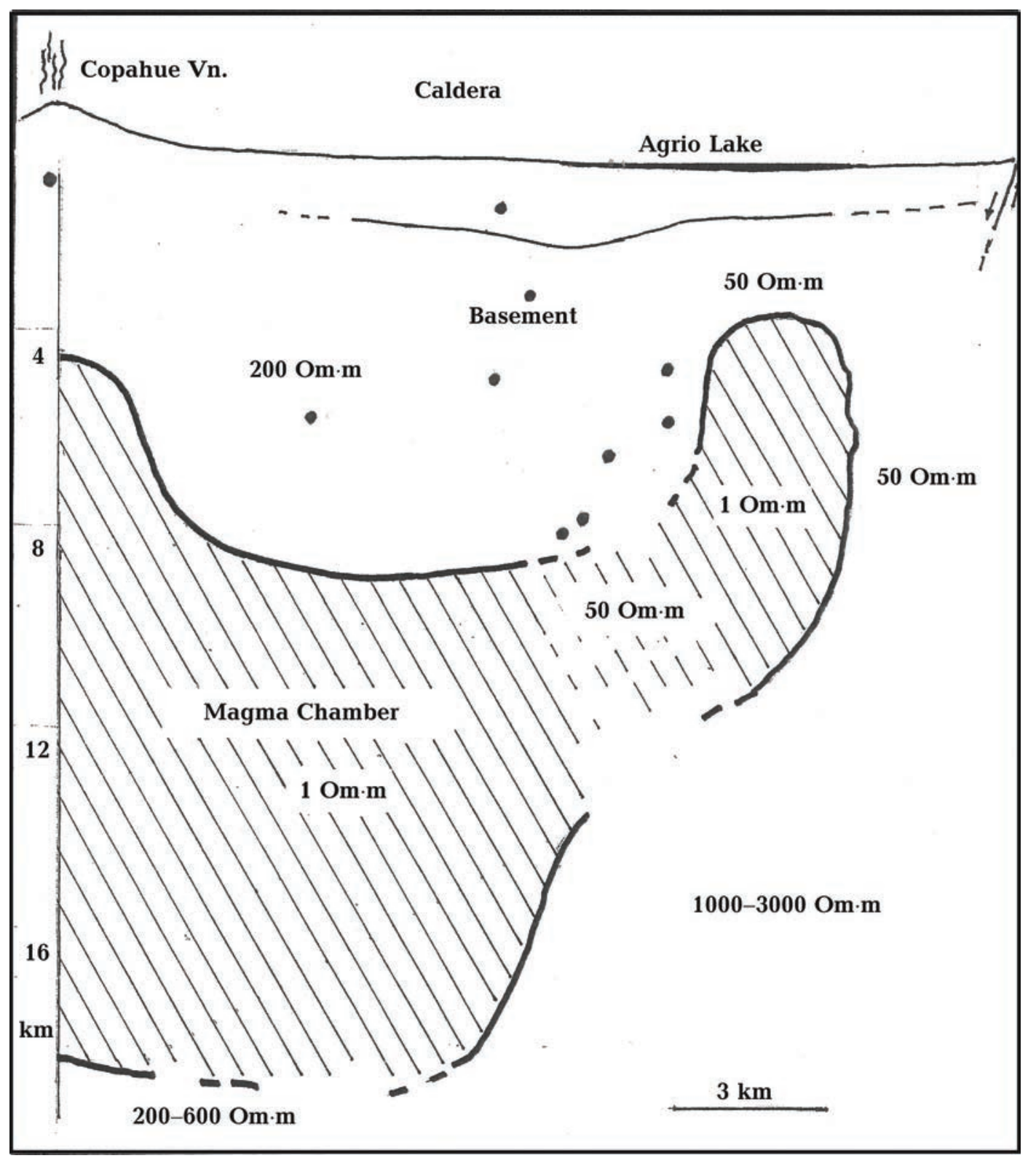

Fig. 7. WE profile at about $37^{\circ} 52^{\prime} \mathrm{S}$ (see Fig. 6, profile AA') shows the considered most adjusting MT interpretation underneath the Copahue caldera, consistent with field data, tectonic and 2D modelling. Shaded area indicates the magma chamber. Ensembles of some seismic hypocentres, corresponding to 2015-2017 are shown (Sernageomin, Servicio Nacional de Geologia y Mineria, Chile). These volcano-tectonic events are associated to rock fracturation (Sernageomin, Chile).

with top at $4-8 \mathrm{~km}$ depth and a bottom at about $18 \mathrm{~km}$. The low resistivity of this body in conjunction with the lithospheric thinness and high heat flow [Mas et al., 2000] are suggesting the conductive body should be considered as a magma chamber, composed by partial melted or melted rocks. However, this body could be perhaps a set of several magma chambers associated with deep faults instead of a unique body.

Therefore, according to the evidence, the following structure beneath the Copahue Caldera is considered: a lithosphere of about $60-66 \mathrm{~km}$ thick, with an upper crust of $8 \mathrm{~km}$ thick and a lower crust of about $10 \mathrm{~km}$ thick (from $8 \mathrm{~km}$ to approximately $18 \mathrm{~km}$ depth) with high conductivity bodies seated at this depth. There are also other conductive bodies 
underneath $\mathrm{C} 6$ and $\mathrm{C} 2$, according to Fig. 6 . This figure also shows the locations of the suggested magma chambers. The magnetovariational study at C2 and C6 sites (see Fig. 4) suggests rather similar conductances at both locations.

Although the lower crust is generally observable by MT (see for instance [Berdichevsky et al., 1976; Muñoz et al., 1990; Jones, 1992]), in the present study, however, the lower crust is not detectable as a conductive layer because there is no evidence in $\rho \perp$ curves (see Fig. 3,a). The explanation could be related, according to 2D modelling results (see Fig. 6), to a strong anisotropy in resistivity presents in the lower crust, with strong lateral heterogeneity between the western and eastern zones of the caldera. In addition, the high conductivity of the volcanic sediments on the basement, with highly mineralized hot water, could be screening the lower crust [Berdichevsky et al., 1989]. As a conclusion, the Copahue's Caldera seems to be divided into two zones: the eastern one, with resistivity at the lower crust of about 1000-3000 $\Omega$ m; and the western one with resistivityof $200 \Omega \mathrm{m}$ at lower crust, and magma chambers seated at this depth.

The Copahue Volcano region is linked to the Liquiñe-Ofqui Fault (LOF), which run in Chile. According to [Melnick et al., 2006; Radic, 2010], at $38^{\circ} \mathrm{S}$ this fault crosses the Andean Range toward Argentina and, southward of $38^{\circ} \mathrm{S}$ in Chile, the Quaternary volcanism is strongly controlled by this fault, where it is associated directly or indirectly with the main effusive centers. In fact, south of Chile, at about $39^{\circ} \mathrm{S}$ a MT study was carried out close to Villarrica Volcano [Muñoz et al., 1990] showing a conductive body between about 40 to $80 \mathrm{~km}$ depth with $60 \Omega \mathrm{m}$ of resistivity. At the same time, MT and magnetovariational studies performed between $38^{\circ} \mathrm{S}$ and $41^{\circ} \mathrm{S}$ [Brasse, Soyer, 2001; Brasse et al., 2009], show, among others conductive zones, a very conductive body at $39^{\circ} \mathrm{S}$, close to Llaima Volcano in the range of depths of $18-30 \mathrm{~km}$, with about $1 \Omega \mathrm{m}$ of resistivity. These conductive bodies are linked to the Liquiñe-Ofqui fault.

In order to compare the consistence of the resulting structure with other physical parameters, estimates of heat flow were accomplished using empirical formulas [Adám, 1978] which link heat flow to the depth of thermal conductive layers. From the depth corresponding to the top of magma chambers, suggested in the crust, and the suggested asthenosphere depth, gross estimates of heat flows are possible to obtain. Empirical formula linking geoelectric information and heat flow studies, from Eastern Europe, were used [Adám, 1978]:

$$
\begin{gathered}
h=35 q^{-1,3} \text { (crust), } \\
h=155 q^{-1,46} \text { (upper mantle), }
\end{gathered}
$$

where $h$ - depth of the first conductive layer (FCL) in the crust, and intermediate conductive layer (ICL) in the upper mantle, in $\mathrm{km}$; $q$ - regional heat flow in HFU (1 HFU= $=1 \mu \mathrm{cal} / \mathrm{cm}^{2} \mathrm{~s} \approx 42 \mathrm{~mW} / \mathrm{m}^{2}$ ).

Considering, in the first formula, a value for h among 3 to $8 \mathrm{~km}$, estimates of heat flows among $130-278 \mathrm{~mW} / \mathrm{m}^{2}$ were obtained for the caldera zone above the magma chambers (see Fig. 6). These values are consistent with an average heat flow of $162 \mathrm{~mW} / \mathrm{m}^{2}$ obtained from 12 wells drilled inside the caldera [Mas et al., 2000]. These results confirm the thermal origin of the conductive bodies in lower crust indicating melted or partially melted rocks, and correct depths of conductive bodies obtained by magnetotelluric studies. From the second formula, considering the depth of asthenosphere of about $60-66 \mathrm{~km}$, heat flows of $75-80 \mathrm{~mW} / \mathrm{m}^{2}$ are estimated, thus suggesting the main part of heat flow comes from the lower crust.

Fig. 7 shows a possible tectonic interpretation which is considered as the most accurate, according to all evidences presented here. Taking into account that the estimated heat flow in the Copahue's Caldera, and the lithospheric thickness suggested by data (about $60-66 \mathrm{~km}$ ) are similar to thermal conditions in a rift, a gross estimate of the lower crust temperature can be obtained. As an approximation, using the $P T$-diagram after [Feldman, 1976], and considering a rift zone, a range of temperatures of about $600-1000{ }^{\circ} \mathrm{C}$ is thus estimated for the lower crust under the Cal- 
dera.

A preliminary article about the Copahue Volcano was published [Mamani et al., 2000]. Using data from 4 magnetotelluric soundings, the thermal structure underneath the volcano was suggested. Comparing those results with these obtained from the present study, it is evident a general consistent. Both studies indicate low resistivity $(1-17 \Omega \mathrm{m})$ from about $8 \mathrm{~km}$ and deeper depths below the caldera. However, differences in the interpretation are also evident. In fact, in [Mamani et al., 2000], the high conductivities suggested by data were supposed to be located underneath the MT sites into the caldera, while in the present work, according to the present geological information, they are considered as produced by magma chambers linked with deep faults located at the western zone of the caldera. It is evident from this comparison the great importance to have solid geologic information in order to postulate the most probable model of structure for the study zone.

Conclusions. Taking into account all results, we can synthesize the conclusions as follow:

1) subsidence of basement inside the Copahue Caldera, relevant to surrounding region, is about 700-1400 m;

2) asthenosphere is suggested with top to about $60-66 \mathrm{~km}$ depth, thus indicating a lithospheric thinness. The evidence is however not completely reliable, according to the data;

3) the crust in the zone would be constituted by an upper crust of about $8 \mathrm{~km}$ thickness, and a lower crust from 8 to about $18 \mathrm{~km}$ depth. A magma chamber seems to be seated at the lower crust with top between 4 and $8 \mathrm{~km}$ depth. This magma chamber is located at the western zone of Copahue Caldera, close to Copahue Volcano at the border between Chile and Argentina. It may be a set of several smaller mag- ma chambers linked to different faults instead of a unique chamber. Other smaller magma chambers are suggested at the eastern border of the caldera, even though they could be associated with the main chamber just mentioned;

4) lower crust is not detectable by MT as a conductive layer. This characteristic could be explained by a strong lateral heterogeneity in resistivity and probably the conductance of lower crust is lower than the sediment conductance on the basement, inside the caldera. The eastern zone of lower crust inside the caldera seems to have resistivity among 1000 and $3000 \Omega \mathrm{m}$, meanwhile the western zone has a resistivity of $200 \Omega$;

5) magma chambers present, according to $2 \mathrm{D}$ modellings, an electrical resistivity of $1 \Omega \mathrm{m}$, suggesting partially melted or melted rocks:

6) heat flow of among $130-278 \mathrm{~mW} / \mathrm{m}^{2}$ is estimated inside the caldera, using empirical formulas and taking into account the proposed tectonic model fitted by 2D modelling. These values are rather consistent with estimates of heat flow obtained from wells drilled into the caldera;

7) according to estimates of heat flow from the depth of conductive body in the crust and the depth of asthenosphere, in the upper mantle, the main part of heat flow would come from the lower crust;

8) a gross estimation of temperature of $600-1000{ }^{\circ} \mathrm{C}$ is made for magma chambers at lower crust;

9) a lifting zone at the top of basement is suggested at C6 site.

Acknowledgement. The authors thank for the help and collaboration of Horacio Tassone and Ernesto Horne in the field data acquisition. We also thank J. Venencia for field data processing and O. Di Giuseppe for his help in field. D. Dueñas (MAGRAF, CONICET Mendoza) is also thanked for drawing some figures. 


\title{
Magma Chamber Associated to Deep Faults in Copahue Active Volcanic Complex, South America, Suggested by Magnetotelluric Study
}

\author{
E. Borzotta ${ }^{1}$, A. T. Caselli ${ }^{2}$, M. J. Mamani ${ }^{1}, 2018$
}

\begin{abstract}
Magnetotelluric studies were carried out in 1993 and 2008 inside the caldera of Copahue Volcanic Complex, located in South America, at the border between Chile and Argentina $\left(37^{\circ} 51^{\prime} \mathrm{S} ; 71^{\circ} 10.2^{\prime} \mathrm{W}\right)$. The main effusive centre of this complex is the Copahue Active Volcano, which constitutes an important geothermal zone. The study of the crust and the investigation of possible magma chambers were the objectives of this survey. Six magnetotelluric soundings were interpreted taking in mind the geologic and tectonic background. Two 2D bimodal modelling along two profiles approximately perpendicular to geological strike were performed. In addition, two magnetovariational studies were made, using two magnetic variometers. Induction (Wiese) vectors were thus estimated for three MT sites. Among the results, the lithosphere in the region is suggested to be $60-66 \mathrm{~km}$ thickness, with upper and lower crusts of $8 \mathrm{~km}$ and $10 \mathrm{~km}$ thickness respectively. A magma chamber is suggested at lower crust with top at $3-8 \mathrm{~km}$ depth, with $1 \Omega \mathrm{m}$ of resistivity, thus indicating partial-melting or melted-rocks. Data suggest this chamber could be genetically associated with a deep fault system into the caldera. Heat flows of $130-278 \mathrm{~mW} / \mathrm{m}^{2}$ were estimated at surface, above magma chambers, using empirical formulas linking depths of thermal conductive layers, in the crust and upper mantle, with heat flows values measured at surface. The estimated heat flows, thus obtained, are rather consistent with heat flows measured in wells drilled into the caldera.

Taking into account that magnetotelluric soundings, at present, are not usual in volcanic studies, the present work may give valuable information about this active volcano, (which at present is in yellow alert), mainly because there are people living at about $15 \mathrm{~km}$ from the volcano or less in Argentina and Chile. In addition this study is important from geothermal point of view, for the possibility to obtain energy without air contamination.

Key words: Copahue volcano, magnetotelluric study, magma chamber, heat flows, Earth's crust.
\end{abstract}

\section{References}

Adám, A. (1978). Geothermal effects in the formation of electrically conducting zones and temperature distribution in the Earth. Physics of the Earth and Planetary Interiors, 17(2), 21-28. https://doi.org/10.1016/0031-9201(78)90046-8.

Berdichevsky, M. N. \& Dmitriev, V. I. (1976). Basic principles of interpretation of magnetotelluric sounding curves. In: A. Adám (ed.), Geoelectric and Geothermal Studies, KAPG Geophysical Monograph (pp. 165-221). Budapest: Akadémiai Kiadó.

Berdichevsky, M. N., Chernyavsky, G. A. \& Alperovich, I. M. (1976). Deep magnetotelluric surveys in Sakhalin. In: A. Adám (ed.), Geoelectric and Geothermal Studies, KAPG Geophysical Monograph, (pp. 702-707). Budapest: Akadémiai Kiadó.
Berdichevsky, M. N., Vanyan, L. L. \& Dmitriev, V. I. (1989). Methods used in the U.S.S.R. to reduce near-surface inhomogeneity effects on deep magnetotelluric sounding. Physics of the Earth and Planetary Interiors, 53(3-4), 194-206. https://doi.org/10.1016/0031-9201(89)90003-4.

Brasse, H., \& Soyer, W., (2001). A magnetotelluric study in the Southern Chilean Andes. Geophysical Research Letters, 28(19), 3757-3760.

Brasse, H., Kapinos, G., Li, Y., Mutschard, L., Soyer, W. \& Eydam, D. (2009). Structural electrical anisotropy in the crust at the South-Central Chilean continental margin as inferred from geomagnetic transfer functions. Physics of the Earth and Planetary Interiors, 173(1-2), 7-16. https://doi.org/10.1016/j.pepi.2008.10.017. 
Feldman, I. S. (1976). On the nature of conductive layers in the Earth's crust and upper mantle. In: A. Adám (ed.), Geoelectric and Geothermal Studies, KAPG Geophysical Monograph (pp. 719-730). Budapest: Akadémiai Kiadó.

Folguera, A., Ramos, V. A. \& Melnick, D. (2003). Recurrencia en el desarrollo de cuencas de intraarco. Cordillera Neuquina $\left(37^{\circ} 30^{\prime}-38^{\circ} \mathrm{S}\right)$. Revista de la Asociación Geológica Argentina, 58(1), 3-19.

Gonzalez Diaz, E. F. (2005). Geomorfología de la region del volcán Copahue y sus adyacencias (centro-oeste del Neuquén). Revista Asociación Geológica Argentina, 60(1), 72-87.

Jones, A. G. (1992). Electrical conductivity of the continental lower crust. In: D. M. Fountain, R. J. Arculus \& R. W. Kay (Eds.), Continental Lower Crust (Chapter 3, pp. 81-143). Elsevier.

Mamani, M. J., Borzotta, E., Venencia, J. E., Maidana, A., Moyano, C. E. \& Castiglione, B. (2000). Electric structure of the Copahue Volcano (Neuquén Province, Argentina), from magnetotelluric soundings: 1D and 2D modellings. Journal of South American Earth Sciences, 13(12), 147-156. https://doi.org/10.1016/S08959811(00)00011-0.

Mas, L., Mas, G. \& Bengochea, L. (2000). Heat flow of Copahue geothermal field, its relation with tectonic scheme. Proc. World Geothermal Congress. Kyushu-Tohoku, Japan, May 28-June 10 (pp.1419-1424).

Melnick, D., Folguera, A. \& Ramos, V. A. (2006). Structural control on arc volcanism: The Caviahue-Copahue complex, Central to Patagonian Andes Transition ( $\left.38^{\circ} \mathrm{S}\right)$. Journal of South American Earth Sciences, 22(1-2), 66-88. https://doi.org/10.1016/j.jsames.2006.08.008.
Muñoz, M., Fournier, H., Mamani, M., Febrer, J., Borzotta, E. \& Maidana, A. (1990). A comparative study of results obtained in magnetotelluric deep soundings in Villarrica active volcano zone (Chile) with gravity investigations, distribution of earthquake foci, heat flow empirical relationships, isotopic geochemistry $87 \mathrm{Sr} / 86 \mathrm{Sr}$ and SB systematics. Physics of the Earth and Planetary Interiors, 60(1-4), 195-211. https:// doi.org/10.1016/0031-9201(90)90261-U.

Naranjo, J. A. \& Polanco, E. (2004). The 2000 AD eruption of Copahue Volcano, Southern Andes. Revista geológica de Chile, 31(2), 279-292. http://dx.doi.org/10.4067/S071602082004000200007.

Pesce, A. H. (1989). Evolución volcano-tectónica del Complejo Efusivo Copahue-Caviahue y su modelo geotérmico preliminary. Revista Asociación Geológica Argentina, XLIV(1-4), 307-327.

Radic, J. P. (2010). Las cuencas cenozoicas y su control en el volcanismo de los Complejos Nevados de Chillán y Copahue-Callaqui (Andes del Sur, 36-395). Andean Geology, 37(1), 220-246. http://dx.doi.org/10.4067/S071871062010000100009 .

Rokityansky, I. I. (1982). Geoelectromagnetic Investigation of the Earth's Crust and Mantle. Springer. $380 \mathrm{p}$.

Stern, Ch. R. (2004). Active Andean volcanism: its geologic and tectonic setting. Revista geológica de Chile, 31(2), 161-206.

Wannamaker, P. E., Stodt, J. A., \& Rijo, L. (1987). Finite element program for solution of magnetotelluric responses of two-dimensional Earth resistivity structure. Earth Science Laboratory, University of Utah, Research Institute. 